\title{
C-E Translation Practice of the Chapter "Maritime Silk Road of the Indian Ocean" of the Book The Silk Road
}

\author{
Min Shen \\ Xi'an Aeronautical University, Xi'an, China
}

\begin{abstract}
The Silk Road written and edited by Professor Liu Yingsheng introduces the origin, rise and decline of the Silk Road and its unique status in world history. Through describing the evolution of the Silk Road and history and geography of countries along the route, this work reproduces the prosperity of the Silk Road at a time dated back to thousands of years ago. The chapter "Maritime Silk Road of the Indian Ocean" excerpted from the book describes intense cultural exchanges between ancient China and India, presenting hard evidence of strong ties between these two civilizations. This paper starts with brief introductions to source text analysis and translation preparations including pre-translation, while-translation and post-translation proofreading are then exemplified. Translation difficulties such as translation of proper names, specifically names of places and nations and of books and translation of classical Chinese are analyzed with examples and solutions proposed for reference.
\end{abstract}

Index Terms-The Silk Road, Maritime Silk Road of the Indian Ocean, translation difficulties and solutions

\section{INTRODUCTION}

Since the Belt and Road Initiative was proposed, China has further pursued its ambition of sharing development fruits with other countries and rejuvenating exchanges of ancient Silk Road. More background information related to the Silk Road requires to be spread overseas to get more countries involved. The book The Silk Road introduces the exchanges between different civilizations at ancient times, citing books, diaries, scholars' research and records of different historical periods. Historical objectivity is the soul of translating this book. If the translator's carelessness causes miscommunication and unnecessary misunderstandings, the role the translator played as a "cultural bridge" shall be greatly reduced, which is not conducive to cultural communication. Eugene Nida (2004) defines that "translation consists in reproducing in the receptor language the closest natural equivalent of the source language message, first in terms of meaning, and secondly in terms of style"(p. 12). The translator is supposed to fully convey the meaning and style of the source text. This paper shall analyze the translation of the chapter "Maritime Silk Road of the Indian Ocean" of the book The Silk Road and provide the translator's original translation to inspire discussions on translating Silk Road text.

\section{SOURCE TeXt ANALysis}

The book Silk Road digs into ancient Chinese civilization in details and introduces cultural communications among ancient Chinese and other civilizations along the Silk Road. As its English version, this book focuses on promoting Chinese culture and briefing foreign readers this legendary history on the basis of accurate information delivery. The chapter "Maritime Silk Road of the Indian Ocean" includes six parts: busy sailing routes of the Indian Ocean, the climax of cultural exchanges between China and India, blend of Sino-India literature and art, Sino-India exchange on science and technology, vegetarianism, and the Indian Ocean rim recorded in ancient Chinese books. Generally speaking, the language of the translated text is plain, objective, and easy to understand. However, direct quotations from records are common, for example, “其奉正朔, 修贡职, 航海岁至, 逾于前代矣” “众宝既丽, 火布尤奇” “梵人长于 音, 所得从闻入, 华人长于文, 所得从见入”, etc. These quotations must be translated on the basis of accurate understanding. Paraphrasing and liberal translation should be adopted to maintain the readability of the text while retaining cultural image as much as possible.

\section{TRANSLATION PREPARATION}

Translation process mainly includes pre-translation preparation, while-translation and post-translation proofreading.

\section{A. Pre-translation}

Preparation before translation is necessary, which mainly includes learning translation tools and checking reference websites and dictionaries. During preparation, the translator first watched the large-scale TV series documentary named "Silk Road" jointly produced by Japan's NHK and China Central Television in the 1980s. This excellent documentary 
inspired the translator's exploration of ancient Chinese civilization and realized the responsibility of spreading Chinese culture and ancient Chinese civilization through translation. The translator then read through the text and browsed parallel texts and related cultural background, covering Buddhist culture, ancient aeronautical navigation, Indian phonetics, Sanskrit and Chinese phonology, etc. Parallel texts, processing certain textual functions and characteristics which reflect their target language's genre norms, can serve as good guides for translators in translating, proofreading and correcting throughout the whole translation process. (Li Jiayu, 2016, p. 40-41)

\section{B. While-translation}

The translator developed a detailed translation plan to translate 1500 words per day and sorted out high-frequency proper names to build a term base to remove some obstacles for later translation.

\section{Post-translation Proofreading}

Proofreading can not be ignored in translating. Peter Newmark proposed that translators should take fifty to seventy percent of their efforts proofreading their works on the basis of difficulty of the source text. Proofreading is divided into two processes: self-proofreading and peer-proofreading. Self-proofing is mainly aimed at information omission and mistakes while peer-proofreading focuses on inconsistent terminology and misunderstandings of the text. Feng Qinghua (2008) holds that proofreading firstly is to check whether the translation accurately expresses the meaning and information of the source text and secondly is to verify whether the translation conforms to language expressions of the target text and whether it is smooth and concise. In this way, "translationese" can be avoided for maximum (p.14).

\section{TRANSLATION DifFiCUlTIES AND SOLUTIONS}

In this translation task, the translation difficulties encountered mainly include translation of proper nouns and classical Chinese.

\section{A. Translation of Proper Nouns}

Difficulties in translating proper nouns are mainly about translation of places and nations and of books. The translator applies transliteration and annotation and literal translation to solve these difficulties.

a. Name of places and nations

Transliteration and annotation: A large number of ancient country names and place names can be found in the source text. Transliteration and annotation is used to facilitate readers to understand names and locations at both ancient and modern times and to deepen their understanding of the ancient Indian Ocean Silk Road.

Example 1: 大秦

Translation: Daqin (Imperium Romanum)

Example 2: 林邑

Translation: Linyi (present middle of Vietnam)

Example 3: 大食

Translation: Tazi (Arabian Empire)

Analysis: The word "Qin" can be easily reminiscent of the Qin dynasty (221-206 BC). It was mistaken for referring to the Xianyang area in Shaanxi, but in fact "Great Qin" was the area of Roman Empire and the Near East area called by ancient Chinese. "Tazi" was a Chinese term for the Arabs, the Arabian Empire, Arabian muslins and Iranian muslins during the Tang and Song dynasties. "Linyi" refers to central area of Vietnam today. Annotations of these geographic concepts are keys to understand the maritime Silk Road of the Indian Ocean.

b. Name of books

Literal interpretation: A large number of ancient Chinese and Indian books are mentioned in this book. For some ancient books whose name does not directly reflect the main information, explanatory words are added to the literal translation to help readers understand as semantic and communicative translation are the core of translation (Peter Newmark, 1988, p. 45). Literal interpretation is applied to retain the form and content of book name, reflecting the principle of fidelity.

Example 4: 《梵语千字文》

Translation: Thousand-Character Classic in Sanskrit

Example 5: 《梵语杂名》

Translation: Names of Sanskrit

Example 6: 《佛国记》

Translation: Journey in Buddhist Countries

Example 7: 《一切经音义》

Translation: Sound and Meaning of Tripitaka, Annotation of Sanskrit

Analysis: The concise and clear translation of these three books has refined the key information. In the book Sound and Meaning of Tripitaka, plentiful phonological exegesis document of characters in mediaeval times were recorded in Hui Lin's Sound and Meaning of the Tripitaka in the Tang dynasty, which have important value in the history of Chinese linguistics. This book is an annotation book, especially on sound and meaning of Tripitaka. 
Transliteration annotation method: For some traditional ancient books, transliteration annotation method can fully retain the original information while bringing Chinese culture to readers.

Example 8: 《搜神后记》

Translation: Soushenhouji (Sequel of Stories of Immortals)

Example 9: 《博物志》

Translation: Bowuzhi (Ancient Encyclopedia)

Analysis: Chinese pinyin, easy to remember, carries cultural connotation behind books with an English explanation in the bracket indicating the theme and culture for foreign readers. This also helps to spread traditional Chinese culture and promote cross-cultural communication.

\section{B. Translation of Classical Chinese}

Compared with modern Chinese, classical Chinese is much more concise. Two main reasons account for it. One is that monosyllabic words are the overwhelming majority in classical Chinese words. The other is that the omission of the subject and conjunctions are common in classical sentences (Chen Zhijie, 2009, p. 52). A large number of historical records and personal diaries are mentioned in this book, involving a large number of direct quotes in classical Chinese language. To translate classical Chinese, accurate understanding is a prerequisite and flexible use of translation skills is a guarantee. The translation methods mainly include inversion, omission, amplification, literal translation, literal translation and combination.

Inversion: As the Chinese, especially classical Chinese are very different in terms of form, structure and exemplification compared to English, it is necessary to make appropriate adjustments to the form and structure of the original sentence. The translation methods and techniques mainly used by translators are lexical order adjustment, syntactic conversion and change of voice to make the translation coherent and smooth.

Example 10: 上述《服昌蒲方》的末尾提到: “天矢摩揭陀国王舍城邑陀寺三藏法师跋摩米帝以大业八年与突 厥国使主，至武德六年七月二十三日为洛州大德护法师净土寺主矩师笔译出。”

Translation: At the end of the "Chang Pu remedy", it mentioned that it was translated by Master Sanzang, Bamomidi of Yituo Temple of Rajgir, capital of Mojietuo, Tianzhu, along with an envoy of Turk, from the eighth year of Daye to July 23rd, the sixth year of Wude, for Dade, Buddhist guardian master in the Jingtu Temple in Luozhou.

Analysis: Li Changshuan (2008) points that due to the omission of subject, some classical Chinese look like structurally run-on sentence and their translation requires segment and hierarchy in accordance with the meaning and importance. (p. 205). For long classical Chinese text, the priority is to segment the long sentence into chunks on the basis of accurate understanding: If it is not verified on the Internet, the first half of this sentence may be mistakenly punctuated as“天䇥摩揭陀国王/舍城邑陀寺/三藏法师/跋摩米帝/以大业八年/与突厥国使主”. In this sentence,“国 王” does not refer to the "king”, it should be segmented. In fact, “王舍城” refers to “Rajgir”, an early capital of Mojietuo, one of the sixteen major nations of the Buddha era (6-4 BC) at the Indian subcontinent. As this paragraph continues discussing the translation of "Chang Pu remedy" of the previous paragraph, the translator uses passive voice to make the paragraph more coherent and adjusts the last and most important information of the original text at the front of the sentence and rearranges the order of time and place for better understanding.

Omission is to omit words that do not conform to the thinking patterns, language expression of the target language, mainly including meaningless words or repetitions etc. to avoid redundant translation. Although classical Chinese are concise and frequently use four-character words, sometimes information must be integrated and reorganized.

Example 11:据文献记载, 南朝宋齐时有十余国沿海路入华。梁时许多海外番国奉中国南部政权为宗主国, “其 奉正朔, 修贡职, 航海岁至, 逾于前代矣”。

Translation: According to the literature, during Song and Qi in the Southern Dynasties, more than ten countries came to China along the coast. During Liang in the Southern Dynasties, many overseas dependencies submitted to southern China regime as their suzerain. It is said more countries than the previous dynasty sailed to pay their tributes.

Analysis: In the quotation, the meanings of “其奉正朔” “修贡职” and “海外番国奉中国南部政权为宗主国”may seem different but they nearly mean the same thing. "Zhengshuo" refers to the first day of a year. Here it means the political conception of "orthodox regime", which is the result of the development of ancient destiny theory, the great thought of unification thought and the huayi distinction. In the source text, repetitions have occurred many times. Although the author has fully expressed the meaning, the original quotations in the ancient books should be cited as evidence and supplement to further emphasize the historical facts. For this kind of sentence, the translator applies liberal translation and omission sometimes. For superfluous information, remove the quotation marks and delete the repeated meanings, for example, in this sentence, "many overseas dependencies submitted to southern China regime as their suzerain" can be retained while the meaning of "orthodox regime" and "Zhengshuo" can be omitted. However, historic records or crucial direct quotations should be kept in order to maintain its authenticity.

Example 12:另外, 慧皎的《高僧传》记康僧会“明解三藏, 博览六经, 天文图纬, 多数综涉”。

Translation: In addition, Hui Jiao's Stories of Eminent Monks recorded that monk Kang was a comprehensive learner who "mastered Buddhist classics, six channels and astronomy".

Analysis: In the source text, “明解” “博览” (read extensively) “综涉” (comprehensive), repeatedly expressed how 
knowledgeable the monk Kang was. In translation, these three Chinese verbs can be summarized with the word “master”, and the verb phrase “多数综涉” is converted into the noun expression “a comprehensive learner” in English, which transforms the subject-predicate structure of the source text into a simple subject-link verb-predicative structure, clarifies the original Chinese illustrations.

Amplification: In order to make the translation easy to understand, vivid, and more in line with the purpose and language habits, interpretive words, connectives, generic words, general words and pronouns are added. In many classical Chinese quotations, the sentence omits the subject. In Chinese-English translation, the translator must add a subject to keep the sentence complete.

Example 13: 据法显记载, “大海弥漫无边, 不识东西, 唯望日、月、星宿而进。若阴雨时, 为逐风去, 亦无 准”。

Translation: According to Fa Xian, "no one knows direction on the infinite sea but navigates the ship by observing the sun, the moon and stars. If it rains, navigators follow the wind."

Analysis: Formally, a structurally run-on sentence seems to have a predicate without subject, but this is also a complete sentence, and it can express intact information just like other sentences. (Guan Lanruo, 2019, p. 11) There is no subject in the citation in the original text, but by understanding the original sentence, it is found that the first sentence omits the subject owner and the second sentence omits the subject navigator, so "no one" and "navigators" are added to the translation.

Literal translation: Literal translation can be used to translate concepts with Chinese characteristic and have already been accepted by westerners.

Example 14: 《五王经》中提到印度医学的病理生理理论, 说: “人由四大和合而成, 一大不调, 百一病生; 四 大不调, 四百四病同时俱作。”《佛开梵志阿经》则云: “天、地、人、物, 一仰四气。一地、二水、三火、四 风。”

Translation: In the book Classics of Wuwang, theories of pathophysiology were discussed as "human's health was controlled by four points. If one was dysfunctional, man shall get one illness and shall get hundreds of illnesses if the four were all dysfunctional. FokaifanzhiaJing said that "the universe, earth, human and object was all controlled by four qi: the earth, the water, the fire and the wind."

Analysis: In the source text, the notion of "four points" can date back to Indian recordings in which they are four basic elements that make up everything. Later it was adapted as a Buddhist term "four qi (also known as chi)"- the earth, the water, the fire and the wind, referring to the force that makes up and binds together all things in the universe. "Four qi" is a renowned term in traditional Chinese medicine and it is literally translated to promote classical Chinese philosophy as well as Chinese medical wisdom.

Example 15:三国时, 吴国丹阳太守万震在《南州异物志》中叙述了南海上船舶的风帆, 说: “外徼人随舟大小 或作四帆, 前后沓载之。有卢头木, 叶如牑形, 长丈余, 织以为帆。其四帆不正前向, 皆使邪移, 相聚以取风 吹。”

Translation: During Three Kingdoms (year 220-280), Wan Zhen, procurator of Wu described sail of boats on the South China Sea "foreign people set four sails in accordance with the size of the boat and combined them in the front and at the back. A piece of Lutou wood was in the shape of a fan with a ten-foot long woven sailing cloth on. The four sails did not face right ahead but were removed to take wind in a better way."

Analysis: The original text discusses the structure of a boat in rigorous and objective language, and the English structure and expression are duplicated in Chinese.

Combination: Chinese, a parataxis language, is often organized by a loose structure with arrangement of information chunks; English is a hypotaxis language with a designed structure. When translating Chinese into English, a trunk structure should be built while combing Chinese short sentences through using conjunctions, participles, prepositions, infinitives, attributive clauses and independent structures.

Example 16:段成式描述的这种植物形状为: “树长三四丈, 围五六尺, 叶似土藤不调。三月生花, 状如蕉花, 有两甲。渐渐开罅, 中有十余房, 子长二寸, 黄白色, 有核, 熟则子黑, 状类干東, 味甘如饴, 可食。”

Translation: Duan Chengshi described the shape of the plant as follows: "the tree, thirty-to-forty-feet long and five-to-six-feet wide, whose leaves looked like vine yet it did not wither. It blossomed in February with two hard petals like banana flowers. Gradually the flower opened, more than ten pistils stood inside as well as two-inch long fruits in yellow and white within which was a stone of the flower. When the fruit was ripe, it looked like a dried date with sweet taste and a black stone."

Analysis: Classical Chinese texts introduce this plant in an order from outside to inside, from flowering to fruition in brief four-character sentences. The translator combines these fragments into three sentences via using the relative pronoun "whose", preposition plus relative pronoun "within which" to introduce an attributive clause, "when" a time adverbial clause. In this way, tedious information in the source text can be avoided.

\section{CONCLUSION}

\section{A. Reflections}


After the translation task is completed, the translator reads through the full text to check an overall coherence and conduct self-verification, accumulates new vocabularies into term base, and summarizes problems encountered in translation. At the same time, attention should be paid to the details throughout the entire translation process, for example, the translation of personal names, place names, dynasties, and epochs must be standardized and titles of books must be italicized. The translation format of references in the text must be aligned, punctuation marks must be used accurately, and uncertain places require certification. In the process of translation, the translator repeatedly searches for some places that have been verified today, and chooses a more authoritative expression. For many ancient books that lack authoritative names, the translator chooses appropriate translation techniques; for unfamiliar fields mentioned in the book such as the introduction of sailing boats, descriptions of some plants, introduction of Sanskrit pronunciation, etc., the translator learns by searching the encyclopedia, comparing pictures and querying parallel English texts. Patience is an important factor to make translation version precise and excellent.

\section{B. Limitations}

Although the translator has strived through this translation practice, many problems have also been exposed and require continual efforts in the future. The biggest problems exposed in translation are insufficient translation proficiencies and weak bilingual transformation. They are mainly reflected in the slow understanding of classical Chinese, and the inability to quickly select and obtain the key information required in the mass of information.

It is necessary to read extensively especially to browse more books about traditional Chinese culture. The translator also needs to further study and master translation techniques, and use appropriate theory and methods in translation practice. To summarize, improving bilingual ability is the fundamental way to improve translation efficiency and quality.

\section{REFERENCES}

[1] Chen, Z. J. (2009). Classical Chinese and literary translation applicability of Classical Chinese in Translation from Foreign Languages to Chinese. Shanghai: Shanghai Foreign Language Education Press, 52.

[2] Feng, Q. H. (2008). An Elementary Course book on Chinese-English, Beijing: Higher Education Press, 14.

[3] Guan L. R. (2019). A practice report on interpreting strategies for structurally run-on sentences in Chinese-English consecutive interpreting based on the interpretive theory - taking the speech "growing up in failures and explorations" as an example, 11.

[4] Li, C. S. (2008). Theory and Practice of Non-literary Translation, Beijing: China Translation Corporation, 205.

[5] Li, J. Y. (2016). Parallel texts and their guidance in non-literary translation. Heilongjiang Education (Theory and Practice), 9 , 40-41.

[6] Nida, E. (2004). The Theory and Practice of Translation Shanghai: Shanghai Foreign Language Education Press, 12.

[7] Newmark, P. (1988). A Textbook of Translation, New York: Prentice Hall, 45.

Min Shen was born in Ningxia, China in 1991. She is currently an assistant in Xi'an Aeronautical University, Xi'an, China. Her research interests cover translation and English teaching. 